\title{
Informal Post-Experiential Learning
}

\author{
Ágnes Szeghegyi \\ Óbuda University, Keleti Faculty of Business and Management, Institute of \\ Enterprise Management, Tavaszmező u. 15-17, 1084 Budapest, Hungary, \\ szeghegyi.agnes@kgk.uni-obuda.hu
}

\section{Viktória Szoboszlai}

Budapest University of Technology and Economics, Department of Management and Corporate Economics, Magyar tudósok körútja 2, 1117 Budapest, Hungary, viktoria.szoboszlai@ flemingeurope.com

\section{Jolán Velencei}

Óbuda University, Keleti Faculty of Business and Management, Institute of Enterprise Management, Tavaszmező u. 15-17, 1084 Budapest, Hungary, velencei.jolan@kgk.uni-obuda.hu

\footnotetext{
Abstract: In this paper, we emphasize the unprecedented problems that the age of shallow knowledge offers. We investigate how navigating in the world of information and communication technology (ICT) innovations and influencing the spreading of memes are affecting those who make the decisions about how we should behave in the "ICT labyrinth". Drawing on the role of key influencers and communities of practice, we offer an alternative framework of emerging learning tools in the post-experiential informal learning ecosystem and investigate the ways of some implementations in corporate practice.
}

Keywords: informal learning; learning ecosystems; learning tools

\section{The New Age of Shallow-Knowledge}

Today it is unnecessary to convince organizations to buy computers since they have already bought them. Today it is unnecessary to convince people to buy computers since they have already bought them. Today it is unnecessary to convince anyone to use computers, as everyone is using them. They are using 
them more or less in order to be faster in something: in mailing, in browsing, etc. Somehow everyone has learned it through much practice. Nevertheless, we should not forget about the generational differences, the different approach of digital natives and digital immigrants. No one had been taught in school how to use Facebook. No lectures were given either on the glorified pros or on the dangerous cons. Today this is a challange, people seem to be concerned more about the cons as the usage of Facebook has been banned at some workplaces. In postexperiential learning, the emphasis needs to be put also on how to become competent in the application of tools. These applications are going viral and memes are being created. Further research is much needed today in how the user gets to know the validation mechanisms of the tools.

The new tools of social communication have necessarily brought an era where all of us (including those who are not using online social platforms) have to rethink learning, knowledge sharing and collaboration in a fundamentally different way than ever before. Instead of deeply thinking in a narrow area, having only superficial knowledge of many things will become more dominant. In 2011, the writer and blogger Nicolas Carr gave his newest book the title "The Shallows: What the Internet Is Doing to Our Brains". He describes how the newest achievements of information technology are distracting us and don't let us focus on one thing at a time and sustain concentration longer. The information overload is urging us to continually browse and "scan" its contents [1]. In knowledge refreshing - which is not the same as educating - the rigid curriculum and formal learning are replaced by cross-functional content that can satisfy curiosity and thus, informal learning can occur. From this mash-up content everyone can take and deal with what they really need; the rest is optional. This new type of learning is more and more loosely-structured, adapting itself in time, space and in tools to the "here and now needs" of the passionate learners. In a post-experiential learning process the participants need to have the opportunity - based on their knowledge levels and preferences - to step up in this "flood-gate-like" process.

Recent reports found that mobiles will outnumber people next year [2]. The question is simple: is there anything that needs to be done today? We can believe the prognosis but we don't have to. We can say now "let's wait and see", and deal with it later. What we cannot do is bury our heads in the sand. This result in the absurd situation that we don't know what those people should know who are refreshing their knowledge in a post-experiential learning process. This reality is what makes the planning of this learning process interesting. In the course of postexperiential learning, having wide but superficial knowledge can be acceptable. It is worth to get away from the world of "deep knowledge superspecialists" who cannot make themselves understood.

That leads us to two problem areas for further investigation:

1. Navigating in the world of ICT innovations

2. Influence on the spreading of memes. 
In the "ICT labyrinth" the challenge is about how to see through this blizzard of information and knowledge, to recognize and filter the junk from the internet. Those whose decisions can affect our behaviour in the "ICT labyrinth" should be protected from two extremes. The first extreme is that on the internet nothing is true as it is not proven, so there is no pre-control. The other extreme is to blindly believe everything which is available on the internet.

The communities of practice (CoPs) [3] and self-organized learning environments (SOLEs) [4] are formed, and the expeditors and promoters of organizational changes are from the members of these communities. They don't believe in the concepts of the majority, they are the minority who are sustaining the momentum of development. "The key people have disproportionately high influence. They are like the kingpins, in bowling, when we hit them, they topple all the other pins" argue Kim and Mauborgne [5]. Malcolm Gladwell writes about the key influencers as connectors who are important not just because they know large number of people. Their importance lies in who they know [6]. In this paper we argue that it might be useful to show the role of key influencers in dissemination of ICT achievements to those who make the decisions how we should behave in the "ICT labyrinth". In the ICT world the "make or buy" dilemma has long survived. It's a fact by now that the software needs to be bought from one of its major producers. It does not really matter from which one, as the reliability of the major producer's software is guaranteed exactly by their existence on the market. It is obvious that each costumer has his preferences that drive his decision.

Sugata Mitra shared in his TED talk that he left a computer in a slum, $500 \mathrm{kms}$ away from Delhi and the kids started using it and playing with it even in the absence of any supervision or formal teaching. A few months later, when he returned the kids wanted a faster processor and a better mouse [3]. This story can be perhaps an example for the informal learning process. In one sense it is not remarkable that the kids learn to use computers as they learn to use mobile phones without any training. What is remarkable is how much they can learn and with how little guidance if their self-motivation, self-discipline and self-organization are encouraged and enabled. Efficient and independent learning means that one is able to learn persistently, to plan his own learning path - individually and in groups as well - and that includes effective time management and information management.

Preferred patterns of learning strategies typical of the individual are interpreted as learning style and can be regarded as an individual characteristic. Certain learning strategies (the method of information acquisition, sense modality) show some sort of stability while others (the method of information processing and its application) show continuous changes [7]. The learner is able to recognize his needs and opportunities, he knows the process of learning which means the acquisition, procession and integration of new knowledge on the one hand, as well as the search and application of guidelines on the other. Efficient and independent learning is encouraging the learner to build his knowledge upon former learning- 
and life-experience and to apply his ability, which is supported by the set of his skills, in the most different of situations.

Efficient and independent learning is characterized by motivation and confidence. Further conditions of independent learning are the creation of a personal learning strategy, the continuous maintenance of motivation, the ability to focus, the critical reflection on the willingness and purpose of learning, and the acquisition, procession and integration of new knowledge. A learner has to be able to work in groups, to share his knowledge, to evaluate objectively his own work and to ask for advice, information, support, if needed. To maintain continuously the positive attitude and the intrinsic motivation to learn, it is indispensable to use the former learning- and life-experience, to explore new learning opportunities and to widely apply what had been learned.

Formal learning is no longer enough, there is a need for informal as well. In the course of informal learning, the learning content - and the knowledge as such learns "on the go". This is a knowledge refresher process whilst not a subject, people are becoming more educated. In this process, the passionate learner can increase his knowledge, while he can frame up new contents as well (learnergenerated content). There are a lot of talks about the anachronism of the informal education, however, it does not seem to become totally unnecessary. Although in the digital world it needs to find a new place and a new role. Today, the digital culture is having a profound effect on the world just like the disruptive technologies of previous eras and new solutions often have an impact on each other as well as on human behaviour. The development of the internet is advanced not only by the technological innovations but also the evolving imagination and desires of millions which give again new momentum to the technological innovations, argues one of the world's top thought-leaders, Sir Ken Robinson who elaborates on weaknesses of informal education in his books and lectures [8]. His thoughts contribute largely to clarify the "formal vs. informal education" dilemma.

\section{Emerging Tools in the Learning Ecosystem}

According to IBM's Survey of 1,709 CEOs, $16 \%$ of organizations say today they are committed to building a social organization and looking for opportunities to increase communication, collaboration and innovation. Tomorrow, 57\% of them say they will be committed to being a social organization [9]. Workplaces can't avoid to become environments that provide an intensely personalized, social experience to attract, develop and engage employees across all generations and nationalities. One of the major forces that will dramatically affect employers is social networking, social media and social learning. Thinking of the $90 \mathrm{~s}$ and 2000 s as the "e"decade, as in e-books, e-libraries and e-learning, we can envision 2010 to 2020 as the "s" decade [10]. 
"Games are the new normal" were the exact words of Al Gore in his iconic keynote speech at the Games for Change Festival back in 2011 [11] and since then, the trend has become even more significant. By 2014, Gartner predicts that over 70 percent of the Forbes Global 2,000 organizations will have at least one "gamified" application, and that "gamification is positioned to become a significant trend in the next five years" [12]. In addition, reports found that gamification market is estimated to grow from $\$ 421.3$ million in 2013 to $\$ 2.8$ billion by 2016 [13] and to $\$ 5.5$ billion by 2018 . This represents a compound annual growth rate (CAGR) of $67.1 \%$ from 2013 to 2018 [14].

A natural ecosystem is a biological community of interacting organisms and their physical environment. Conversely, a learning ecosystem is a self-organizing infrastructure aimed at creating a learning environment for networked members that supports the cooperation, the knowledge sharing, the development of open and adaptive technologies and evolutionary business models. Personal ownership of technologies and devices coupled with access to social software means that all kind of learning-related activity can be e-enabled today and the main challenge lies in the real transition to a less tutor-led approach to learning, becoming competent in the application of these tools and getting to know their validation mechanisms.

The goal of this paper is to describe emerging learning tools within learning networks and the broader learning ecosystem, and to map out the validation mechanisms. To do this, we need to explore in which forms can these learning tools occur and how they are situated within the learning ecosystem (1) as well as what kind validation mechanisms are effective based on the possible use in practice (2). Drawing on the authors' theoretical and empirical research, prior expert advisor feedbacks, and the content analysis of delivered presentations at two consecutive summits with the highest corporate university and academy leader attendance in Europe (Brussels, 2013; Paris, 2012), we will attempt to develop a framework for the emerging tools in corporate learning ecosystems. In 2012, out of 21 sessions 13 indicated the prevalence of social learning and 2 sessions the popularity of gamification. In 2013, this number increased further, up to 15 and 5 respectively, proving how these tools continue gaining momentum.

\subsection{Social Learning Tools as the Engine of CoPs}

Social learning is collaborative, immediate, relevant, and presented in the context of the individual's unique work environment [10]. Social learning tools are distinguished here based on the main purpose of either Community of Practice (CoP)-building or CoP-maintaining. 


\subsubsection{Social Learning Tools for Building CoPs}

"Employees of 2013 initiate their own learning more and more" pointed out the dean of a leading corporate learning institute, Caterpillar University and in this process the importance of being surrounded by CoPs is critical. The question was if we were ready to support social networking tools i.e. Linkedin or Facebook; synchronous and asynchronous communication; shared workspaces and shared media on the changing learning landscape [15]. AGFA Academy underlined this with their approach of linking structured learning and on the job learning, thus linking Learning Management Systems (LMS) to building up CoPs. In the section "What should be in your Educator Toolbox?" AGFA shared how they are disseminating user-generated content via blogs, wikis, the "AGFA Training Community" forum and knowledgebase, while they are using self-paced elearning sessions, virtual classroom sessions and video sharing to deliver content generated by subject matter experts (SMEs). They are using social bookmarking and social tagging - tagging courses so they appear in search results - and allow for communication with coaches, mentors and CoPs via tools like instant messaging, live webcasts and message boards [16].

\subsubsection{Social Learning Tools for Maintaining CoPs}

Social learning should be enabled not only by facilitating the CoP frameworks where this type of learning can occur; there is a need for community "gardening" so that social learning can flourish. Amongst the most powerful CoP-maintaining social learning tools, we would point out blogging (text, audio/video or microblogging i.e. Twitter) and mobile/location-based technologies.

Maintaining a blog gives a permanent presence on the web and serves as a jumping-off point for deeper professional discussions. Employees can get connected and ask for informal peer reviews. In communities of practice, the influence of Gladwell's connectors and the impact of "who" becomes greater than the sum of their parts, knowing who to contact becomes more important than having the right answer.

A geographically dispersed business like Philips, might have a CoP in several functions. Today, tech-savvy employees are using a geo-locator app that allows them to see an expert in a particular function "checked in" at a given location. If it is nearby, users then can contact each other to meet for lunch or to shadow an onthe-job task, making these mobile applications a good way to maintain relationships and share knowledge. Philips Lighting University is particularly strong in maintaining communities and keeping its learners engaged. In 2012, their community's site became the $7^{\text {th }}$ most successful, with 5 webpages in the top 20 most viewed sites, 30,131 unique visitors and an average of 14 minutes per visit from Philips employees who accessed the site based on focus areas, business or functions [17]. ArcelorMittal University created functional academies and introduced collaborative learning that is guided by a virtual network of experts in 
each topic and nurtured by social networks of peers at each location. This strengthened the power of its communities and set the foundations of the ArcelorMittal University's first internal massive open online course (MOOC) [18].

Another real-life validation of a community-enhancing social learning tool is PwC's Spark story about an internal social network embedded in the workflow with the ambitious goals to connect 180,000 employees in 154 countries, to create an attractive work environment for younger employees, and to make a large firm feel small. Spark, a PwC business network using Jive software was launched in spring, 2012. Adoption grew virally as Jive became the hub for PwC employees to collaborate and create value for themselves and their clients. Within six months 90,000 people used Spark and growth continued as $\mathrm{PwC}$ people found innovative ways to derive value from the solution. Since then, $\mathrm{PwC}$ is using Spark to engage employees, locate experts, share knowledge and hold powerful conversations on key strategic issues [19].

\subsection{Gamified Tools as Amplifiers of the Learning Ecosystem}

Gamification is a business strategy which applies game design techniques to nongame experiences. The goals are to achieve higher levels of engagement, change behaviors, and stimulate innovation. Opportunities for employers are great: gaining more engaged customers, improving employee performance, and crowdsourcing internally are all among the benefits gamification can offer. In this paper we argue that game design techniques and game mechanics can be applied in two domains: employer branding and people management.

Employer branding, the desire of most employees to have on their CV a company name that gives a sense of pride ties this type of branding to talent attraction, talent acquisition, and recruiting as such, while people management includes learning and development related, assessment related as well as reward and recognition related policies.

\subsubsection{Branding}

Many organizations now weave employee engagement and learning into the employee life cycle from beginning to end and they create an employment brand to engage people even before they are hired. Marriott was among the pioneers in the industry with the introduction of a gamified platform called "My Marriott Hotel" to generate interest in hospitality careers. Gamers on Facebook had to first manage a virtual hotel restaurant kitchen before moving on to other areas of hotel operations. Ultimately, they were rewarded when their operation turned into profit. Recently, danish shipping and logistics giant Maersk Group made a unique effort with its game "Quest for Oil" to improve transparency in the industry, encourage the interest of school children and university graduates in the energy 
industry, and recruit new talents. Several other examples could be listed amongst the adopters such as HAYS' "Hays Challenge" or PwC's "Multipoly" popularizing recruiting or tax and advisory services and strengthening the brand, which generated a significant increase in candidate numbers and new hires. The most important achievement is to put gamers in virtual immersive environments, virtual worlds such as Siemens' "Plantville" and simulate job tasks in order to become the "employer of choice" for top talents.

The research of this field provides a vast background in terms of game design techniques and game mechanics particularly aligned with employer branding and recruiting goals, which is not the aim of this paper explicitly, rather, we focus more on the People Management part.

\subsubsection{People Management}

An average gamer plays 10,000 hours of games by age 21 . That's about the same number of hours that students spend from $5^{\text {th }}$ grade to graduation of high school. This 10,000 hours ties in with Malcolm Gladwell's theory of success [20] that if we can spend 10,000 effortless hours of study we have a chance to become masters in our area. So what are the gamers becoming masters at? Collaboration, virtual teaming, influencing, problem solving and critical thinking - all core values of the future workplace [19].

In the learning and development field, practice-based insights were provided by a couple of early game-based learning implementations, including Philips Ligthing University's edu-games, Nestlé University's board games combining experiential learning, engagement and fun [21], as well as Yapi Kredi Bank Academy's gamebased trainings and simulations. This latter example is what we would like to elaborate more on in terms of validation mechanisms.

Yapi Kredi Bank had to meet new employee time-to-competency goals and maintain proficiency for 17,000 employees at 900 branches throughout Turkey with this alternative, gamified learning delivery method. "YKB City" was developed with the academy's partners (including Koc University, IMD, INSEAD) and with gaming product vendors. At the conclusion of the game, the top successful employees and top branches were determined and rewarded. Short films about their achievements were then broadcasted on the bank's portal. Enjoyable to play and convenient to use, "YKB City" had become also a popular resource for employees to readily consult learning content by visiting the game's virtual library. As a result, cross-selling performance had improved steadily and YKB City proved to be a cost-saving training tool as well. By delivering the training during off-duty hours via e-learning, Yapi Kredi saved three days 89,460 man hours - that would otherwise have been devoted to classroom training with the same content. Comparing the cost of the game with that of three-day classroom training, the academy realized a savings equal to 5 percent of its annual budget. The impact on job results was also significant. The "incomplete job ratio" 
i.e. for the topic "retail credits" dropped from 53 percent to 18 percent, while the average job waiting time decreased by 25 percent [22].

Over and abover all of these success stories, according to Gartner, $80 \%$ of current gamified applications will fail to meet business goals by 2015 and poor game design is one of the key failings of many gamified applications today. For a gamified application to truly engage its audience three key design ingredients must be present and correctly positioned: motivation, momentum, and meaning (collectively known as " $\mathrm{M}^{3 "}$ ) [23]. Motivation and momentum are also provided by continuous feedback, rewards, and recognitions that are applied as must-have elements in the game-based learning apps of the corporate learning practice. Their design has to provide incentives to learn. Leaderboards and badges are two ways that games engage and reward learners by recognizing their achievements and making them visible to others. Taking the simple example of social media platforms, such as Facebook and LinkedIn, they use badging too, in the form of "likes" and "endorsements", to drive participation.

Massive open online courses, better known as MOOCs, are at the forefront of a movement to revolutionizre what we call "traditional learning environments". In our technology-enabled era when anyone anywhere anytime can access high quality higher education at little to nocost, MOOCs are also facing challenges where gamification-based course design might be the answer.

Learners (people anwhere at any point in their lives who want to learn) in the "ICT labyrinth" are increasingly being guided by "content curational advice" and consructing their own educational "playlists".

However, while MOOC enrollments are stratospheric, their completion rates are extremely low.

Table 1 depicts information on the world's largest three MOOC platforms today. Stanford-born Coursera leads the way with over 4,000,000 total enrolments, the Stanford University spin-off Udacity has mounted the second highest number with over 1,500,000 enrollments and the Harvard-MIT collaboration edX is in in third place, with only about a quarter the enrollments of Coursera [24].

According to Coursera's information on completion rates given to partner universities, out of the 3,4 million registrants in Coursera's first year 55\% never completed one lesson and 3-5\% of those who started a class actually completed it [24].

Table 1

Top 3 MOOC Platforms

\begin{tabular}{|l|c|c|c|c|}
\hline & Foundation & $\begin{array}{c}\text { Number of } \\
\text { Students }\end{array}$ & $\begin{array}{c}\text { Number of } \\
\text { Universities }\end{array}$ & $\begin{array}{c}\text { Number of } \\
\text { Courses }\end{array}$ \\
\hline Coursera & April 2012 & Over 4 million & 83 & 393 \\
\hline Udacity & February 2012 & Over 1,5million & 2 & 25 \\
\hline edX & May 2012 & Over 1 million & 28 & 44 \\
\hline
\end{tabular}


MOOC or not, the not-for-profit Khan Academy (launched in 2006) did plant a seed to help MOOCs grow into the phenomenon they are in today. While a MOOC can be classified as a "transplantation" of a traditional course, the ondemand capabilities of the Khan Academy's more than 4,000 videos, interactive challenges and assessments as elements cannot be found with a standard MOOC. This organization seems to lead the way also in how to address the issue of low completion rates. The Khan Academy with a mission to make education more accessible by providing free world-class resources to anyone, anywhere, is using now gamification to drive learners through the learning journey, rewarding them with badges as they complete classes.

More information on standard MOOCs where game design elements and game mechanics are embedded in the course design would help us to establish a greater degree of accuracy on this matter. Therefore further investigation would be needed to identify a more exact definition for gamification-based MOOC design and to determine the correlation between game-based learning paths and MOOC completion rates.

\section{Discussion}

As learning moves out of the classroom and into the "ICT labyrinth" and the hands of learners, the roles of those who make the decisions about how we should behave in this labyrinth are shifting. These decisions are either programmable [25] operating through various forms of self-discipline and control, or nonprogrammable but need a certain level of conducting [26]. We argue that these processes can be increasingly associated with self-disciplined decisions adapting itself in time, space, and tools to the "here and now needs" of the passionate learners.

In this paper, we have first described an alternative framework of emerging learning tools in the post-experiential informal learning process, based on the building blocks of social learning and gamification, then we have identified and situated these tools within the broader learning ecosystem. Secondly, we have tried to map out the effective validation mechanisms based on the possible use in practice. There is a need to link and embed these tools in a "more pluralistic" learning ecology in which both prescriptive and emergent application domains and modes of learning have their place [27]. Self-motivated, self-organized and selfdisciplined informal post-experiential learning should be recognized as a vital part of learning ecosystems in which the application of emerging tools of social learning and gamification can be applied based on the described validation mechanisms.

\section{References}

[1] Carr, N.: The Shallows: What the Internet Is Doing to Our Brains, W. W. Norton \& Company, NY, USA, 2010 
[2] ITU's World in 2013 Report: ICTs Facts and Figures http://www.itu.int/en/ITU-

D/Statistics/Documents/facts/ICTFactsFigures2013.pdf [Accessed at 22 October, 2013]

[3] Wenger, E.: Communities of Practice. Meaning, Learning and Identity, Cambridge University Press, Cambridge, UK, 1998

[4] Mitra, S., \& Dangwal, R. Limits to Self-Organising Systems of Learning The Kalikuppam Experiment. British Journal of Educational Technology, London, UK, 2012

[5] Kim, W. C., Mauborgne, R.: Tipping Point Leadership, Harvard Business School Publishing Company, MA, USA, 2003

[6] Gladwell, M.: The Tipping Point: How Little Things Can Make a Big Difference, Little, Brown and Company, NY, 2000

[7] Tóth P.: Learning Strategies and Styles in Vocational Education, Acta Polytechnica Hungarica, 9(3), pp. 195-216, Budapest, Hungary, 2012

[8] Robinson, R.: Out of Our Minds: Learning to be Creative, Capstone, MN (Minnesota), 2011

[9] IBM: IBM 2012 Global CEO Study http://www.slideshare.net/ArtilleryMarketing/ibm-global-ceo-study [Accessed at 22 October, 2013]

[10] Meister, J., Willyerd, K.: The 2020 Workplace, HarperColling Publishers, USA, NY, 2010

[11] Gore, A.: Games for the Environment, Games for Change Festival, NY, 2011

[12] Gartner. Gartner Gamification Report 2011, http://www.gamification.org/wiki/Gartner_Gamification_Report_2011 [Accessed at 24 October, 2013]

[13] Meloni, W., Gruener, W.: M2 Report - Gamification in 2012, Market Update Consumer and Enterprise Market Trends, 2012 http://www.m2research.com/gamification-2012.htm [Accessed at 24 October, 2013]

[14] Markets and Markets. Gamification Market [(Consumer Gamification, Enterprise Gamification) by Deployment (On-Premise, On-Demand); Application (Marketing, Sales, Hr, Support, and Development); Size (SMB, Enterprise)]: Worldwide Market Forecasts and Analysis (2013 - 2018), 2013 http://www.marketsandmarkets.com/Market-Reports/gamificationmarket-991.html [Accessed at 24 October, 2013] 
[15] Kronenburg, R.: Running a Corporate University: Right Learning, Right People, Right Time...All The Time! - Caterpillar University, Proceedings of the $3^{\text {rd }}$ Corporate Universities and Ac@ demies Summit Brussels, 2013

[16] Hove, B.: A Cost Effective Global Learning Strategy with High ImpactWhat Should Be in Your Educator Toolbox? - AGFA Academy, Proceedings of the $3^{\text {rd }}$ Corporate Universities and Ac@demies Summit Brussels, 2013

[17] Hooydonk, S.: Learning @ Philips Lighting - Philips Lighting University, Proceedings of the $3^{\text {rd }}$ Corporate Universities and Ac@demies Summit Brussels, 2013

[18] Standaert, C.: Guiding the Corporate University through Turbulent Times ArcelorMittal University, Proceedings of the $3^{\text {rd }}$ Corporate Universities and Ac@demies Summit Brussels, 2013

[19] Mangelsdorf, M.: Learning Design Futurology and the Learning Function 3.0. -2020 Future Workplace Network, Proceedings of the $3^{\text {rd }}$ Corporate Universities and Ac@demies Summit Brussels, 2013

[20] Gladwell, M.: Outliers: The Story of Success; Little Brown and Company, NY, USA, 2008

[21] Rajon, B: The Rive-Reine Experience - How Corporate T\&L can make the difference - Nestlé University, Proceedings of the $3^{\text {rd }}$ Corporate Universities and Ac@demies Summit Brussels, 2013

[22] Önen, S.: Integrating Talent Management Programs with the Corporate Academy Vision - Yapi Kredi Banking Academy, Proceedings of the $3^{\text {rd }}$ Corporate Universities and Ac@demies Summit Brussels, 2013

[23] Brian Burke, research vice president at Gartner - Future of Gamification at Gartner Portals, Content and Collaboration Summit, March 12-14, 2012 in Orlando, FL, USA In: Gartner. Press Release https://www.gartner.com/newsroom/id/1844115?brand=1 [Accessed at 24 October, 2013]

[24] Gallagher, S., Garrett, G.: Disruptive Education - Technology-enabled Universities, The United States Studies Centre at the University of Sydney, 2013

[25] Simon, H.: The Sciences of the Artificial (second edition; first edition 1969) MIT Press, Cambridge, MA, USA, 1981

[26] Mintzberg, H.: Covert Leadership: Notes on Managing Professionals, Harvard Business School Publishing Company, MA, USA, 1998

[27] Williams, R., Karosousou, R., Mackness, J.: Emergent Learning and Learning Ecologies in Web 2.0, International Review of Research in Open and Distance Learning, Alberta, Canada, 2011 